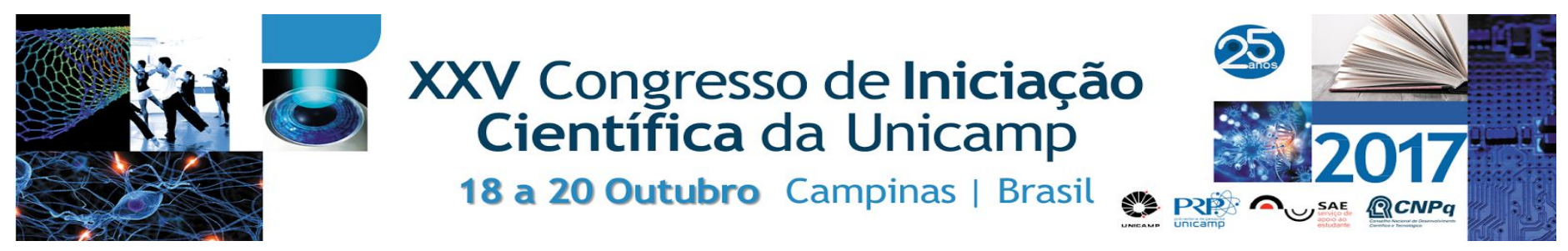

\title{
Expressão, purificação e caracterização estrutural da proteína Hsp110 de sorgo
}

\section{Luiz E.R. Firmino*, Juliana Crotti Franco, Prof. Dr. Carlos Henrique Inácio Ramos}

\section{Resumo}

As proteínas são as macromoléculas mais importantes nas células, pois desempenham diversas funções biológicas nos organismos. Para que as proteínas desempenhem suas funções elas precisam adotar uma estrutura tridimensional estável. Há proteínas capazes de auxiliar na formação da estrutura nativa, conhecidas como chaperonas moleculares, as quais constituem uma família de proteínas que auxiliam na formação da estrutura tridimensional de polipeptídeos clientes, previnem o enovelamento incorreto e a agregação, sendo, portanto, essenciais na manutenção da homeostase proteica. Em animais, identificaram a participação da Hsp110 no sistema da Hsp70, em um sistema de desagregação. A Hsp110 foi analisada por diferentes técnicas como dicroísmo circular e fluorescência, para elucidar sua estrutura e obter informações que ajudem a compreender seu mecanismo funcional. O Sorgo é muito importante para a agricultura sendo o quinto cereal mais produzido no mundo.

\section{Palavras-chave:}

Bioquímica, Proteínas, Co-chaperonas

\section{Introdução}

As Hsp70 são proteínas dependentes de ATP, que previnem a formação de agregados e desnaturação. ${ }^{1}$ Observou-se que a Hsp110 possui um papel importante na desagregação e reativação de agregados em mamíferos ao interagir com o sistema da Hsp70. Além disso, a interação entre Hsp110 e o sistema Hsp70 quando na presença da Hsp100, não presente em metazoários, mostrou aumentar a eficiência da atividade desta desagregase. ${ }^{2}$ Esse trabalho focou na expressão, purificação e caracterização da Hsp110 de sorgo para melhor entender seu papel no sistema da Hsp70 das plantas.

\section{Resultados e Discussão}

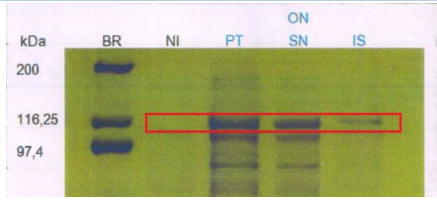

Figura 1. Teste de expressão em BL21(DE3) a $18^{\circ} \mathrm{C}$ por 16 horas (Overnight).

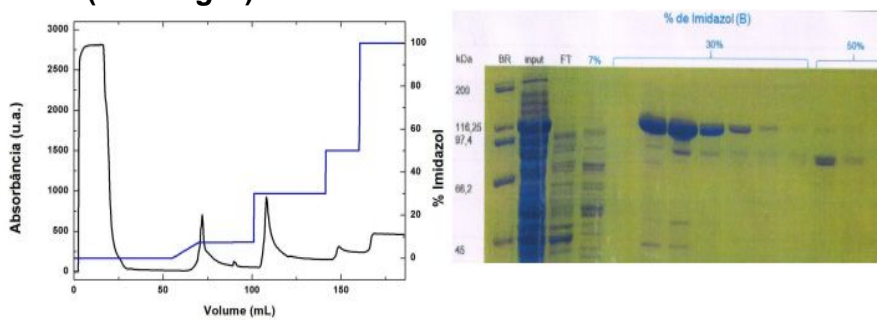

Figura 2. Cromatograma de afinidade e respectivo gel de SDS-PAGE.

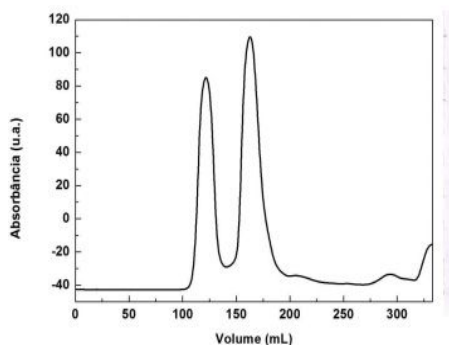

Figura 3. Cromatograma de exclusão molecular e respectivo gel de SDS-PAGE.
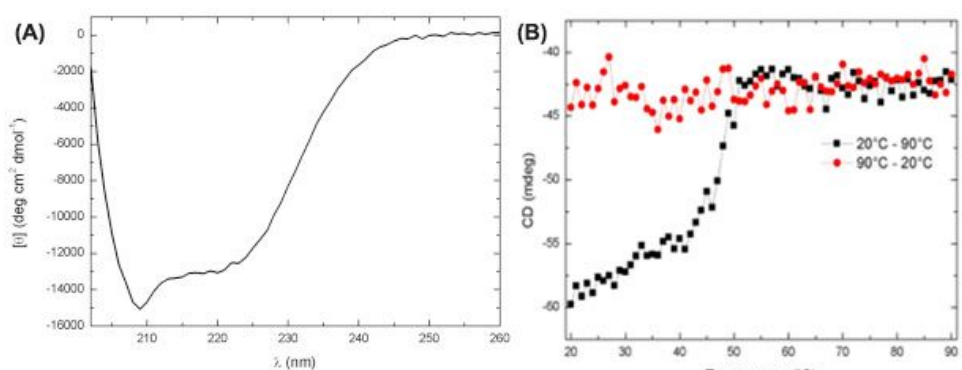

(C)

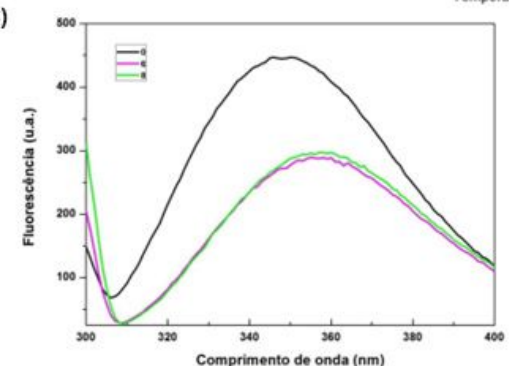

Figura 4. (A) Caracterização da estrutura secundária da Hsp110 através do dicroísmo circular (B) Desenovelamento térmico da $\mathrm{Hsp} 110$, de $20^{\circ} \mathrm{C}$ a $90^{\circ} \mathrm{C}$, monitorado pelo sinal de dicroísmo circular a $222 \mathrm{~nm}$ (C) Espectro de emissão de fluorescência do triptofano da Hsp110 (295 nm).

\section{Conclusões}

A expressão e purificação da Hsp110 de sorgo foi bem-sucedida, ela apresenta perfil predominante de alfa-hélice em seu espectro de CD, seu desenovelamento térmico é irreversível e pelo menos um de seus triptofanos está no interior da proteína e é exposto com o desenovelamento químico.

\section{Agradecimentos}

UNICAMP, Instituto de Química, PIBIC/CNPQ, FAPESP e CAPES.

1. Borges JC, Ramos CH. Protein folding assisted by chaperones. Protein Pept Lett. 2005 12, 257- 261

2. Shorter, J. The Mammalian Disaggregase Machinery: Hsp110 Synergizes with Hsp70 and Hsp40 to Catalyze Protein Disaggregation and Reactivation in a Cell-Free System. PLoS ONE 2011 6(10): e26319. 